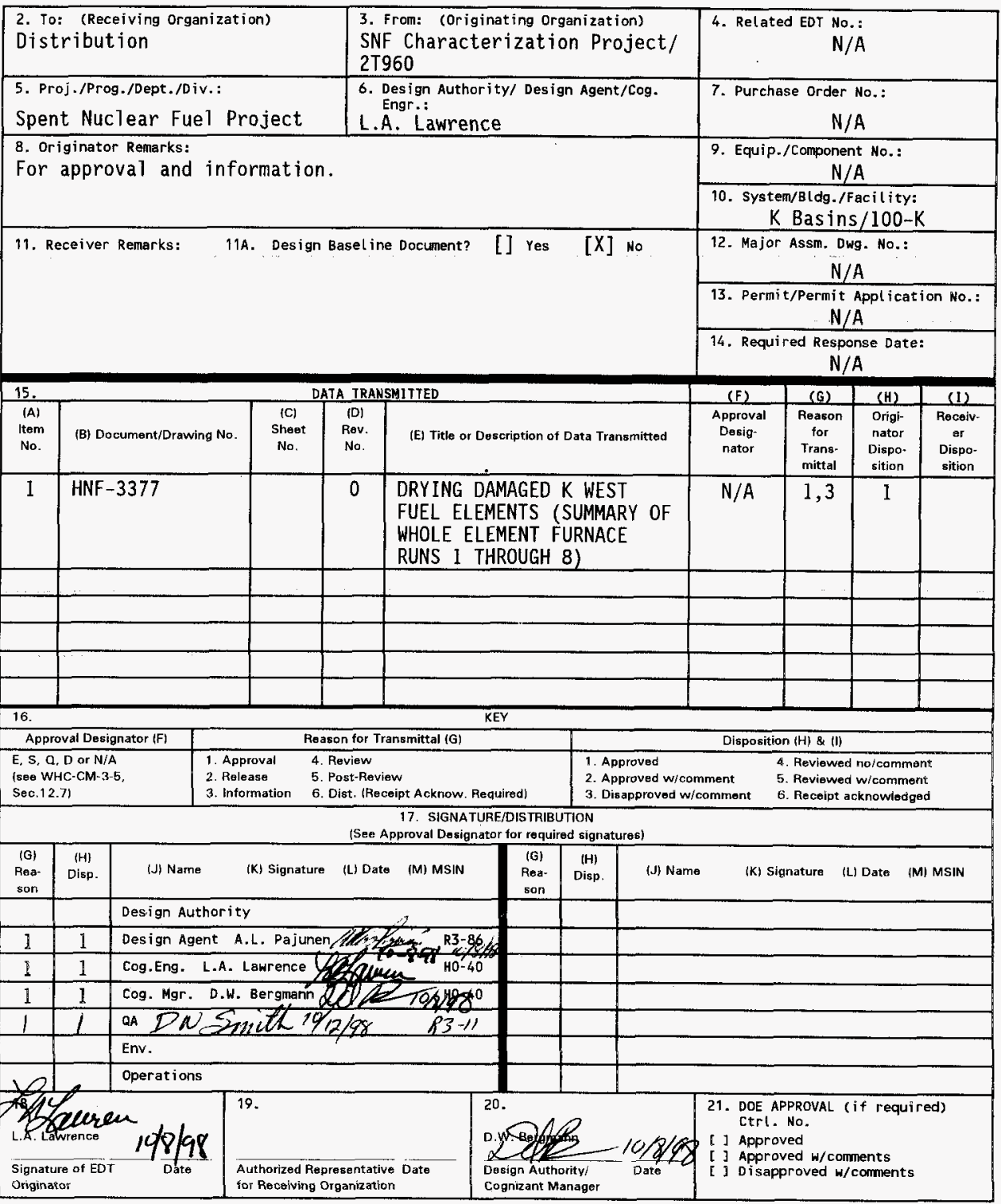


HNF-3377, Rev. 0

\section{DRYING DAMAGED K WEST FUEL ELEMENTS (SUMMARY OF WHOLE ELEMENT FURNACE RUNS 1 THROUGH 8)}

\section{A. Lawrence}

Duke Engineering \& Services Hanford, Inc, , Richland, WA 99352

U.S. Department of Energy Contract DE-AC06-96RL13200

EDT/ECN: 620816

Org Code: 2F700

B\&R Code: EW7040000
UC: UC 2070

Charge Code: 105356

Total Pages: $4240,10 \times 3$ is

Key Words: Whole Element Drying, Damaged K West Fuel, 105-K West, Spent Nuclear Fuel

Abstract: $\mathrm{N}$ Reactor fuel elements stored in the Hanford $\mathrm{K}$ Basins were subjected to high temperatures and vacuum conditions to remove water. Results of the first series of whole element furnace tests i.e., Runs 1 through 8 were collected in this summary report. The report focuses on the six tests with breached fuel from the $K$ West Basin which ranged from a simple fracture at the approximate mid-point to severe damage with cladding breaches at the top and bottom ends with axial breaches and fuel loss. Results of the tests are summarized and compared for moisture released during cold vacuum drying, moisture remaining after drying, effects of drying on the fue 1 element condition, and hydrogen and fission product release.

TRADEMARK DISCLAIMER. Reference herein to any specific commercial product, process, or service by trade name, trademark, manufacturer, or otherwise, does not necessarily constitute or imply its endorsement, recommendation, or favoring by the United States Government or any agency thereof or its contractors or subcontractors.

Printed in the United States of America. To obtain copies of this document, contact: Document Control Services, P.O. Box 950, Mailstop H6-08, Richland HA 99352, Phone (509) 372-2420; Fax (509) 376-4989.
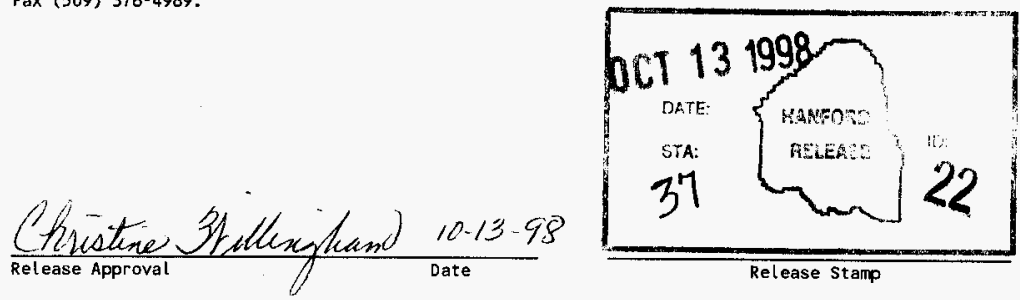

\section{Approved for Public Release}


HNF-3377, Rev. 0

DRYING DAMAGED $K$ WEST FUEL ELEMENTS

(SUMMARY OF WHOLE ELEMENT FURNACE RUNS 1 THROUGH 8)

L. A. Lawrence

October 1998 
Document Title: DRYING DAMAGED $K$ WEST FUEL ELEMENTS (SUMMARY OF WHOLE ELEMENT FURNACE RUNS 1 THROUGH 8)

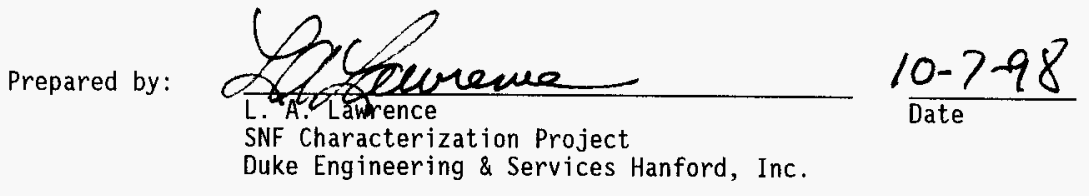

Reviewed by:

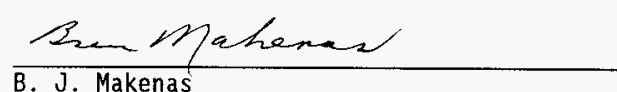

B. J. Makenas

SNF Characterization Project

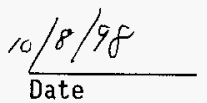

Approved by:

Duke Engineering \& Services Hanford, Inc.

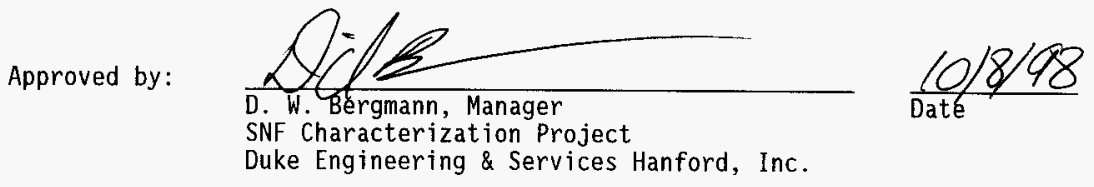




\section{ACKNOWLEDGEMENT}

These tests would not have been possible without the dedication and outstanding performance of Whole Element Furnace Test Team lead by

Dr. Steve Marschman of the Pacific Northwest National Laboratory. Dr. Marschman designed and oversaw the construction of a first of its kind world class system, that operated nearly trouble free for all our planned experiments. The Whole Element Furnace Test Team consisted of the following:

Dr. S. C. Marschman

Dr. G. S. Klinger

Mr. P. J. MacFar1an

Mr. G. A. Ritter

Dr. B. M. 01 iver

Dr. J. Abrefah
PNNL Team Leader

PNNL Scientist, responsible for test operations and data analysis

DESH Laboratory Technician, responsible for dayto-day operations

FDNW Engineer, supporting test designs, fabrication, and operations

PNNL Scientist, supporting data analysis and reporting

PNNL Scientist supporting data interpretation and analysis

The above named individuals from three different companies worked as a real team to complete the planned tests on a very aggressive schedule and their contribution is recognized and greatly appreciated.

These tests would not have been possible without the support of the Postirradiation Test Laboratory operated by B\&W Hanford Inc.

$\mathrm{Mr}$. Norris Johnson is recognized for his expertise in all phases of fuel element handling and transfers within the hot cell facility.

These tests would also not have been possible without the efforts of those within Duke Engineering \& Services Hanford, Inc. needed to identify, collect, and ship the fuel to the hot cells for testing. These people are too numerous to recognize individually but there contribution to this successful tests program is greatly appreciated.

I would also like to thank all my co-workers in the SNF Characterization Project lead by Dr. R. P. Omberg for their support and input to this testing program. 
HNF-3377, Rev. 0

\section{EXECUTIVE SUMMARY}

Seven $K$ West and one $K$ East elements were subjected to high temperatures and vacuum conditions to remove water. Six of the $K$ West outer elements had cladding breaches that ranged from a simple fracture at the approximate midpoint to severe damage with cladding breaches at the top and bottom ends with axial breaches and fuel loss. The first series of Whole Element Furnace Tests has been completed by the Pacific Northwest Nationa1 Laboratory and the results reported. The results of these tests were collected in this summary report which will focus on the six tests with breached elements. Therefore, in general these conclusions relate to these damaged fuel from the $K$ West Basin and extrapolations to basin wide populations should be carefully considered.

Drying under conditions typical of cold vacuum drying (CVD) removed between $10 \mathrm{~m} \ell$ and $30 \mathrm{~m} \ell$ of free water from the six damaged elements. High temperature vacuum drying determined that between $1 \mathrm{~g}$ and $3.3 \mathrm{~g}$ of water remained in the elements after CVD. One element with a translucent coating determined to be aluminum hydroxide released $1.7 \mathrm{~g}$ of water from the coating consistent with independent characterizations of similar coating materials. The amount of water remaining after CVD appears to be relatively insensitive to the extent of fuel damage once there has been fuel degradation and cladding opening. 
The high temperatures that the elements were subjected to resulted in changes in the appearance of the surface coatings and the axial fuel cracks. These changes in the appearance of the axial cracks are generally considered to be the result of oxidation of the underlying fuel material with the corresponding volume increases of the less dense oxides.

Measurable quantities of fission product gases, xenon and krypton, were detected with the down stream mass spectrometer in two of the furnace runs. Isotopic percentages of the fission product gases measured were found to agree closely with calculated values. Fission product gases were released from the undamaged fuel as a result of the oxidation of fuel by available oxygen during the high temperature portions of the tests, i.e., $75^{\circ} \mathrm{C}$ or higher.

Significant quantities of hydrogen were released from the elements due to oxidation of fuel by available water and decomposition of uranium hydrides at the higher temperature. The largest contribution to the hydrogen released was from the uranium hydrides. The individual hydrogen peaks were deconvoluted and the quantity of hydrogen released from the hydride measured. This quantity of hydrogen was converted to the amount of $\mathrm{UH}_{3}$ that was decomposed. The amount of $\mathrm{UH}_{3}$ decomposed ranged from $0.5 \mathrm{~g}$ for the least damaged element to $40 \mathrm{~g}$ from the element with extensive axial cracking. Hydride content was the highest in the element with no end breaches and extensive axial cracking. This appears consistent with metallographic examinations which suggested the hydrides were concentrated in fuel cracks ahead of the oxidized fuel interface. The narrow axial cracks appear to have enhanced hydride formation with minimal fuel oxidation. 
HNF-3377, Rev. 0

\section{CONTENTS}

1.0 INTRODUCTION . . . . . . . . . . . . . . . . . . . 7

2.0 WHOLE ELEMENT DRYING FURNACE . . . . . . . . . . 9

3.0 FUEL ELEMENTS . . . . . . . . . . . . . . . . 11

3.1 FUEL ELEMENT SELECTION ................ 11

3.2 PRETEST FUEL CONDITIONS . . . . . . . . . . . 12

4.0 FUEL ELEMENT DRYING . . . . . . . . . . . . . . . 17

5.0 RESULTS . . . . . . . . . . . . . . . . . 19

5.1 WATER RELEASED DURING COLD VACUUM DRYING . . . . . . . 19

5.2 WATER RETAINED AFTER COLD VACUUM DRYING . . . . . . . 20

5.3 EFFECTS OF HIGH TEMPERATURE DRYING ON FUEL ELEMENT CONDITION . 22

5.4 HYDROGEN RELEASE AND HYDRIDE DECOMPOSITION . . . . . . . 23

5.4.1 Hydrogen Release ................ 23

5.4 .2 Hydride Decomposition ............ . . 24

5.5 FISSION PRODUCTS RELEASED . . . . . . . . . . . . . 25

6.0 REFERENCES . . . . . . . . . . . . . . . . . . . . . . . . 29

6.1 BASELINE REFERENCES FOR FURNACE RUNS 1 THROUGH $8 \ldots \ldots 29$

6.2 SUPPORTING REFERENCES . . . . . . . . . . . . 29

APPENDIX A DRYING RESULTS FOR WHOLE ELEMENT FURNACE

RUNS 3 THROUGH $8 \ldots \ldots . \ldots . \ldots 33$ 


\section{LIST OF FIGURES}

1. Furnace for Whole Element Drying Studies . . . . . . . . . . 10

2. Pretest Condition of Elements (a) 0309M (Run 3)

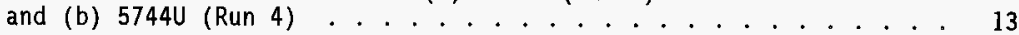

3. Pretest Condition of Elements (a) 6603M (Run 5) and (b) $1164 M$ (Run 6 ) ..................... 14

4. Pretest Condition of Elements (a) 2660M (Run 7) and (b) 65130 (Run 8) ................... 15

5. Normalized Xenon Release During Hot Vacuum Drying of Spent Nuclear Fuel Element 6603M (Run 5) . . . . . . . . 26

\section{LIST OF TABLES}

1. Whole Element Furnace Drying Tests . . . . . . . . . . . . 7

2. K West Elements Selected for Phase I Whole Element Furnace Tests .................. 12

3. Summary of Water Remaining in the Damaged $\mathrm{K}$ West Fuel Elements After Cold Vacuum Drying ............. 21

4. Effects of High Temperature Drying on Fuel Element Condition . . . . 22

5. Summary of Observed Hydrogen Release Peaks During Hot Vacuum Drying ..................... 24

6. Summary of Total Hydrogen Released During Drying and from Hydride Decomposition ............... 25 
HNF-3377, Rev. 0

\section{DRYING DAMAGED $K$ WEST FUEL ELEMENTS \\ (SUMMARY OF WHOLE ELEMENT FURNACE RUNS 1 THROUGH 8)}

\subsection{INTRODUCTION}

Seven $K$ West and one K East elements were subjected to high temperatures and vacuum conditions to remove water. Six of the $K$ West outer elements had cladding breaches that ranged from a simple fracture at the approximate middle of the element to severe damage which included cladding breaches at the top and bottom ends and axial breaches with extensive fuel loss.

Elements were subjected to conditions similar to those expected during cold vacuum drying (CVD) process to determine damaged fuel response to high temperatures and vacuum conditions. Specific areas of interest included drying behavior under anticipated CVD conditions, quantities of residual water remaining after CVD, hydrogen release, and corresponding hydride decomposition. The major variable in the testing series was the extent of fuel damage that was visible on the $K$ West elements.

The first series of tests has been completed by the Pacific Northwest National Laboratory and the result reported (Table l). The results of these tests were collected in this summary report to provide a single source of information and reference for the Spent Nuclear Fuel Project. This summary report will focus on the six tests with breached elements from $K$ West. $A$ complete discussion of each test can be found in the baseline references listed in Table 1 and Section 6.1.

Table 1. Whole Element Furnace Drying Tests.

\begin{tabular}{|c|c|c|l|c||}
\hline $\begin{array}{c}\text { Furnace } \\
\text { Run } \\
\text { Number }\end{array}$ & $\begin{array}{c}\text { Element } \\
\text { Number }\end{array}$ & $\begin{array}{c}\text { Element } \\
\text { Type }\end{array}$ & \multicolumn{1}{|c|}{ Extent of Fuel Damage } & $\begin{array}{c}\text { PNNL Report } \\
\text { Documenting } \\
\text { Test Resu1ts }\end{array}$ \\
\hline 1 & 1990 & $I$ & Undamaged & PNNL-11817 \\
\hline 2 & $3128 \mathrm{~W}^{3}$ & 0 & Undamaged & PNNL-11818 \\
\hline 3 & $0309 \mathrm{M}$ & 0 & Broke in half & PNNL-11820 \\
\hline 4 & $5744 \mathrm{U}$ & 0 & Top breach and axial cracks & PNNL-11821 \\
\hline 5 & $6603 \mathrm{M}$ & 0 & Bottom breach & PNNL-11841 \\
\hline 6 & $1164 \mathrm{M}$ & 0 & Mid-element cracks & PNNL-11896 \\
\hline 7 & $2660 \mathrm{M}$ & 0 & Severe damage & PNNL-11897 \\
\hline 8 & $6513 \mathrm{U}$ & 0 & Severe damage & \\
\hline
\end{tabular}


HNF-3377, Rev. 0

This page intentionally left blank. 
HNF-3377, Rev. 0

\subsection{WHOLE ELEMENT DRYING FURNACE}

The whole element furnace is shown schematically in Figure 1 . The system includes the following subsections: vacuum pumping system, process heat system, gas supply and distribution system, gas analysis instrumentation, process instrumentation and a data acquisition, and control system. The experimental setup is basically a clam shell furnace around an inner retort tube with control thermocouples. The furnace is large enough to handle a complete $N$ Reactor fuel element. The system includes a gas chromatograph and mass spectrometer to analyze the off-gas during the drying process. A complete description of the whole element furnace testing system, including detailed equipment specification, can be found in Ritter (1998).

Minor modifications were made to the system for subsequent testing runs as the test series progressed. Details of these changes can be found in the individual run reports (Section 6.1). 
Figure 1. Furnace for Whole Element Drying Studies.

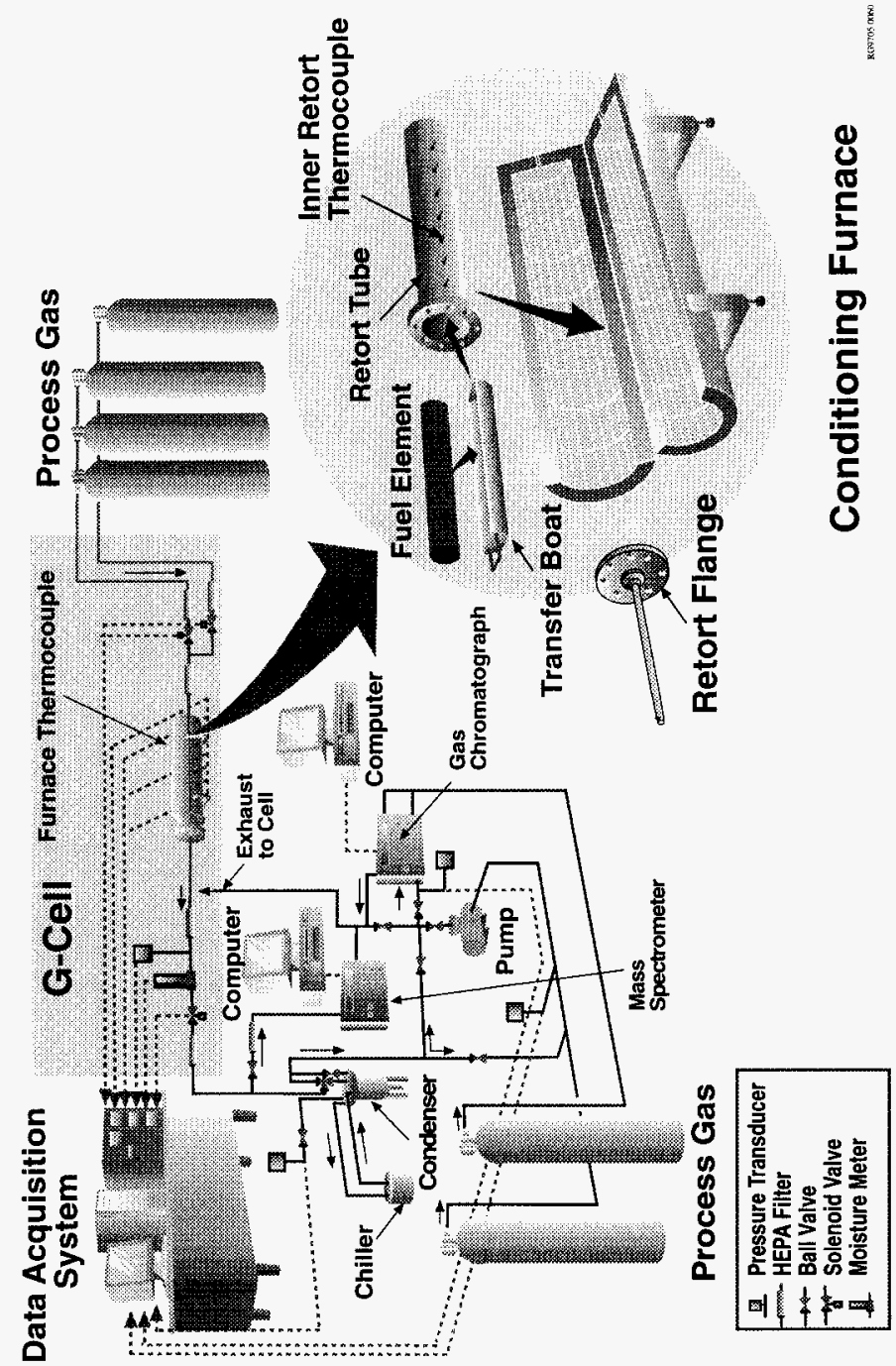


HNF-3377, Rev. 0

\subsection{FUEL. ELEMENTS}

\subsection{FUEL ELEMENT SELECTION}

The Data Quality Objectives (DQOS) for the second group of $K$ West fuel elements selected identified a total of 15 fuel elements for laboratory examinations which included the breached elements for the first phase of the whole element furnace testing (Lawrence 1997a). The initial selection of elements to be sampled was based on the detailed video inspection of over 250 fuel assemblies stored in the sealed canisters (Pitner 1997a). Elements were selected with a range of damage but emphasis was placed on obtaining samples with the greatest extent of different appearing damage that could be handled during the sampling process. This fuel is considered to be representative of the most degraded fuel that can be handled and dried as whole elements.

The damaged fuel in the $K$ West Basin was grouped for the purpose of this selection with the following general characteristics for sampling.

1. Cracked Fuel--Damaged fuel elements were observed with extensive cracks on the outer surfaces with and without significant outer damage.

2. Broken End Caps--Damaged fuel with displaced and missing top and/or bottom end caps was found during the visual examinations and is similar to damage seen in the $K$ East Basin. However, in the case of $K$ West there appears to be less sludge trapped within the damaged fuel compared to $K$ East fuel with similar broken or missing end caps. This is evidenced by the lack of sludge dripping from cracks.

3. Broken Fuel--Fuel elements were examined that broke into large pieces somewhat similar to the $K$ East fuel. These broken ends of the elements do not show the fuel loss generally seen with end cap failures.

4. Severely Damaged Fuel--K West fuel elements with a combination of missing end caps, extensive fuel loss, axial cracking, deformation, and fractured large pieces have been seen. This is, in general, what was observed in $K$ East for the severely damaged fuel.

An attribute driven sampling $\mathrm{plan}$ for the damaged fuel similar to the strategy selected for the K East fuel examination (Lawrence 1996a) was selected resulting in a sampling matrix which included elements with the general characteristics outlined above.

The actual condition of the samples retrieved from the sealed containers and shipped to the hot cells were established from the video coverage during the sampling process. Elements were selected from the inventory and a strategy developed for the whole element furnace testing (Lawrence 1997b, 1998). 
Damaged elements selected for the first series of furnace tests to determine the effects of differing extent of visible fuel damage on the drying characterization are listed in Table 2. Elements are referred to by the designation of their source storage canister barrel.

Table 2. K West Elements Selected for Phase I Whole Element Furnace Tests.

\begin{tabular}{||c|l||}
\hline Element & \multicolumn{1}{|c|}{ Characteristics } \\
\hline $0309 \mathrm{M}$ & Broken in half-represent minimum fuel damage \\
\hline $5744 \mathrm{U}$ & Damaged top \\
\hline $6603 \mathrm{M}$ & Damaged bottom \\
\hline $1164 \mathrm{M}$ & Mid element cracks \\
\hline $2660 \mathrm{M}$ & Severely damaged \\
\hline $6513 \mathrm{U}$ & Severely damaged \\
\hline
\end{tabular}

\subsection{PRETEST FUEL CONDITIONS}

The identified fuel elements for whole element furnace drying remained in basin water filled individual shipping containers until they were required for testing. Elements were removed from their shipping containers and visually inspected using a high resolution video camera. Each element was rinsed by raising and lowering it several times in its storage container to remove any loosely adhering sludge, fuel particulates, or surface coatings. Detailed photographs of each element before and after drying can be found in their reference reports 1 isted in Section 6.1. In-basin conditions of the elements selected for furnace Runs 3 through 8 during sampling in the basin are shown in Figures 2 through 4.

The condition of the elements selected for testing were compared to the damage categories used in the $K$ Basin surveys to provide a tie for these measurements to the overall condition of the fuel in the basins. The condition of the fuel in the K East and $K$ West Basins was catalogued into the following four categories for the assessment of the video fuel surveys (Pitner 1998a).

Intact - No evidence of cladding breach or deposited sludge.

Breached - Minor cladding rupture with no reacted fuel or deposited sludge visibly present.

Defected - Definite evidence of cladding breach with reacted fuel egressing from the element. The amount of exposed fuel may be significant, but there is no gross cladding splitting, element dilation, or fuel voiding.

Bad - Gross failure is evident with substantial element dilation, cladding splitting, fuel "mushrooming," or fuel voiding. 


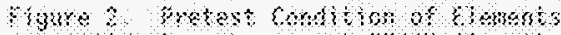

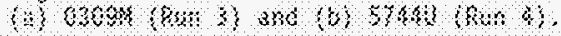

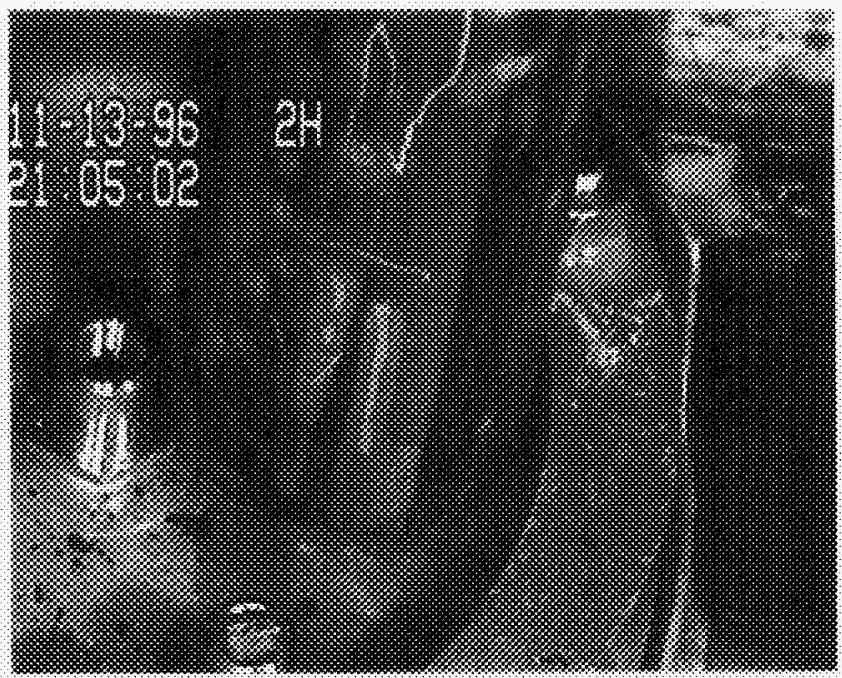

$10,0,150 \mathrm{~s}$

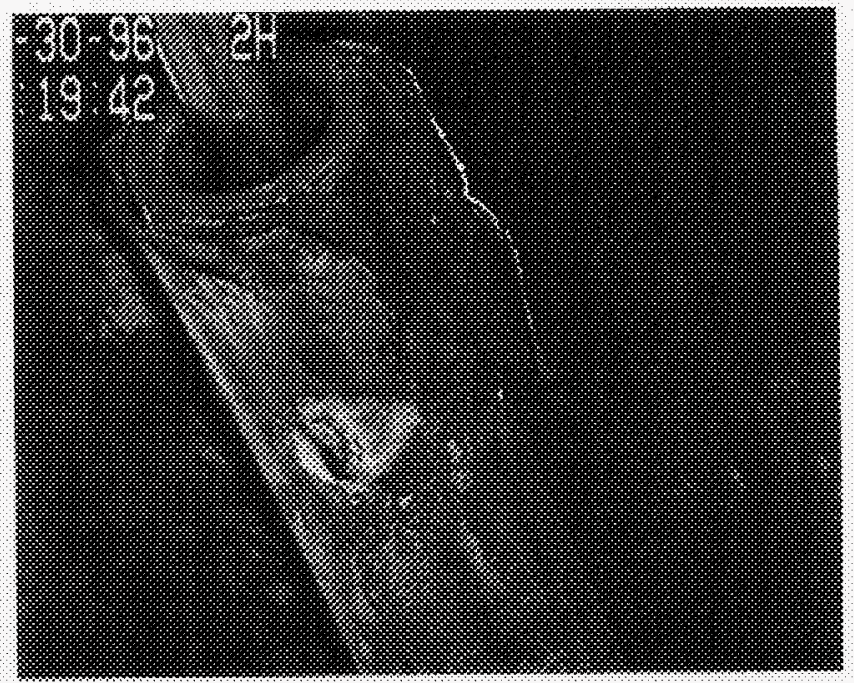

$10,1,8 n, 2,46$ 


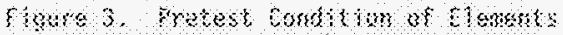

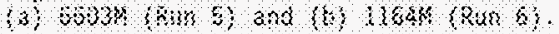

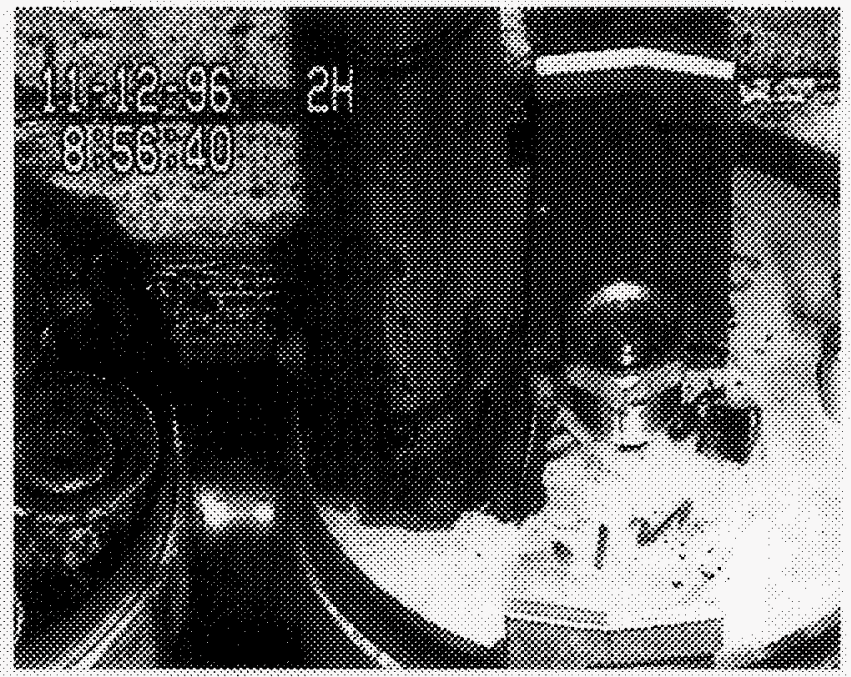

$1,10 \mathrm{nn}, 6 \mathrm{6m}$.

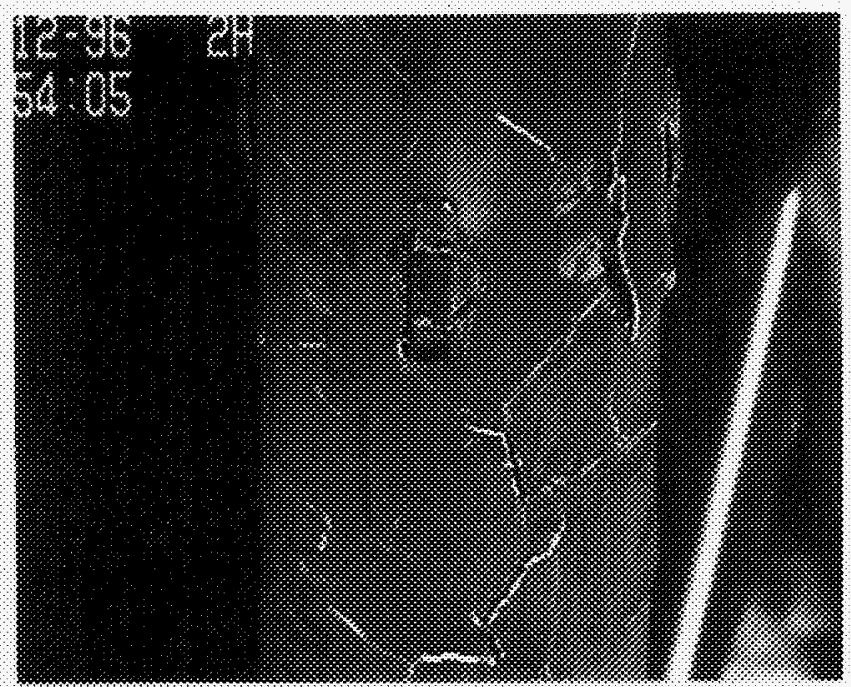

$181,00 n, 104$, 


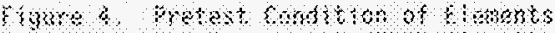

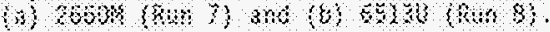

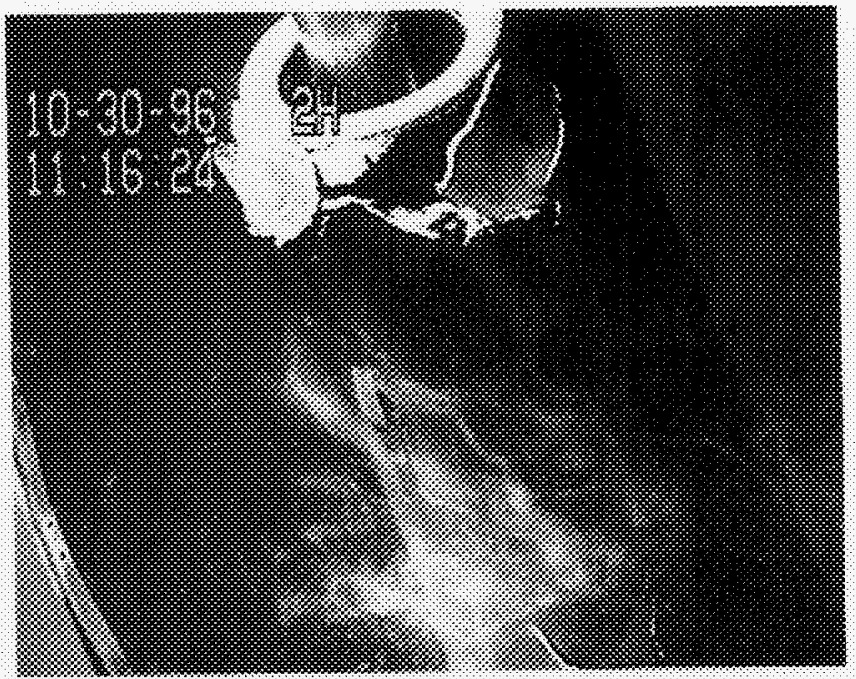

(2) $3, \mathrm{smnt}, 660 \mathrm{~s}$.

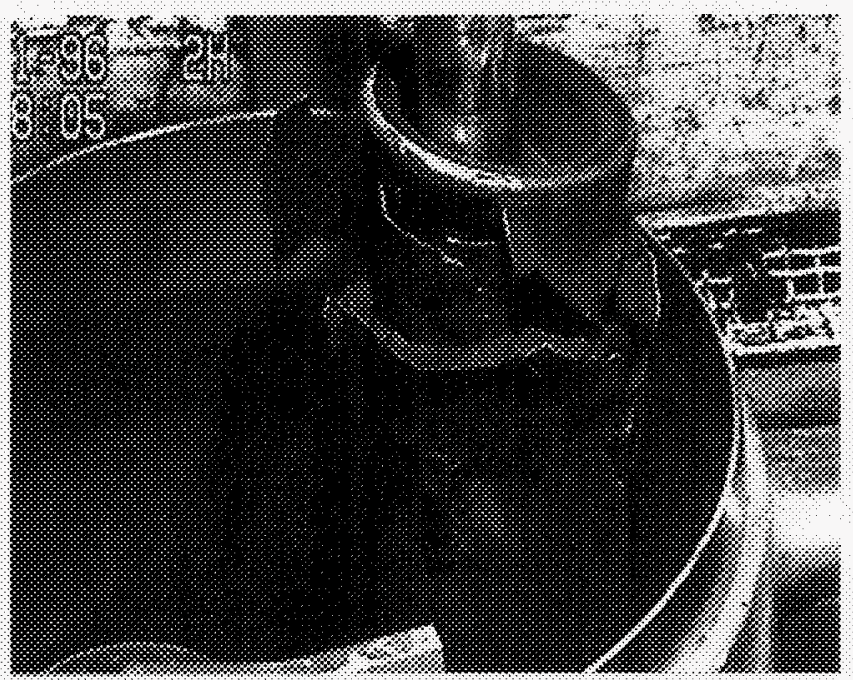

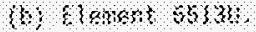


HNF-3377, Rev. 0

Element 0309M falls within the category of "breached" whereas the remaining five damaged elements are considered to be "bad." A11 of the elements contained a surface coating characterized as a thin gray coating on the cladding except for Element $0309 \mathrm{M}$ which was covered by a relatively thick translucent coating (Pitner 1997b). This translucent coating has been characterized to be an aluminum hydroxide, $\mathrm{Al}(\mathrm{OH})_{3}$, whereas, the light gray coatings were characterized as iron based compounds (Makenas 1998). 
HNF-3377, Rev. 0

\subsection{FUEL ELEMENT DRYING}

The fuel element drying cycle consisted of the following six steps

1. Cold vacuum drying (CVD) at $50^{\circ} \mathrm{C}$

2. Pressure rise test at $50{ }^{\circ} \mathrm{C}$

3. Hot vacuum drying (HVD) at $75{ }^{\circ} \mathrm{C}$

4. Hot vacuum drying from $75{ }^{\circ} \mathrm{C}$ to $400{ }^{\circ} \mathrm{C}$

5. Hot vacuum drying at $400{ }^{\circ} \mathrm{C}$

6. Post-test pressure rise test at $50{ }^{\circ} \mathrm{C}$

Specific details of the temperature and pressures for each furnace run can be obtained in the reference documents in Section 6.1

The intent of Steps 1 and 2 was to duplicate the CVD conditions expected for the elements. Specific CVD conditions may have changed since the test plans were developed, however, these conditions duplicate temperature and pressure within the constraints of the experimental equipment.

The remaining four steps in the temperature cycle are designed to determine the quantity of water remaining after CVD as well as the amounts of hydrogen and volatile fission products that could be released at elevated temperatures.

The temperature and pressure cycles for the furnace were selected to answer some of the following questions that were raised in the DQ0 process for these examinations (Lawrence 1997a).

- How long does it take to dry damaged $K$ West elements under the CVD and HVD conditions?

- How much water remains in the fuel element after drying that may be released to react with the fuel under storage conditions.

- How much fuel degradation will be expected during drying and conditioning?

- How much hydrogen will be released from the fuel elements during the drying process that must be accommodated by the process equipment?

Two dry runs with the system were conducted to establish baseline performance without an element in the furnace. Results of these baseline runs can be found in the corresponding references ( $\mathrm{Kl}$ inger 1998c and 1998d). 


$$
\text { HNF-3377, Rev. } 0
$$

A total of eight fuel elements were dried in the whole element furnace for the first phase of the testing. The test matrix is summarized in Table 1. The first two elements tested were undamaged to verify operations of the system and provide baseline data with actual unbreached elements (Marschman 1998a; Flament 1998). The first run utilized an undamaged inner element from $K$ West that was one of the first three elements sampled. The only apparently undamaged outer element in the available inventory of elements was from the $K$ East Basin. This undamaged element, i.e., 3128W, was utilized for the second run. This element was considered to be unbreached based on its detailed visual examinations in the hot cell (Pitner 1997b). The six remaining tests included all damaged fuel elements from $K$ West (Lawrence 1997a). Fuel damage ranged from a relatively clean fracture with little or no fuel reaction and loss to severely damaged elements with open breaches at both ends, open axial fuel cracks, and significant fuel loss. 
HNF-3377, Rev. 0

\subsection{RESULTS}

Detailed results for each furnace run can be found in the baseline references in Section 6.1. Summary plots of the drying results from Runs 3 through 8 obtained from damaged $K$ West fuel elements are included in Appendix A.

The results of the first two tests with undamaged fuel confirmed that they were unbreached. A small quantity of water was released from the $\mathrm{K}$ East outer Element $3128 \mathrm{~W}$ in Run 2. A total of $0.34 \mathrm{~g}$ of water was released. The small quantity of water released from this unbreached $K$ East element is ascribed to the surface coating. Fuel elements stored in the $K$ East Basin are characterized by the presence of a thin gray coating on the outer surfaces (Pitner 1997c). Chemical analysis of similar coatings for $K$ East show them to be uranium based compounds (Makenas 1998). Coatings found on elements from $K$ West that are similar in color, were found from examinations of surface coatings, to be primarily iron based compounds. This quantity of water released corresponds to a coating thickness approximately $1.5 \mathrm{mg} / \mathrm{cm}^{2}$ for the expected uranium hydrate (Abrefah 1998a).

Thermo-Gravimetric Analysis (TGA) of the gray coating removed from $K$ East fuel element surfaces support the conclusion that the thermal decomposition of the dehydrate $\mathrm{UO}_{4} \cdot 2 \mathrm{H}_{2} \mathrm{O} \rightarrow \mathrm{UO}_{3}+2 \mathrm{H}_{2} \mathrm{O}+1 / 2 \mathrm{O}_{2}$ is responsible for the sample weight loss in the range of $100^{\circ} \mathrm{C}$ to $400{ }^{\circ} \mathrm{C}$. Scanning Electron Microscopy of these coating materials shows the presence of needle shaped particles suggesting they are precipitation products from fuel corrosion. Converting the samples collected in this examination to a surface concentration resulted in a value of $0.6 \mathrm{mg} / \mathrm{cm}^{2}$ (Abrefah 1998a). This is somewhat less than predicted from the drying of the undamaged $3128 \mathrm{~W}$ element but may be well within the variation in thickness of the gray coating for $K$ East elements. Therefore, results of the moisture released during drying are consistent with characterization of similar coatings removed from other $K$ East elements and examined.

Results of the drying of the six breached elements will be discussed in the following sections related to quantities of water released and retained, amounts of hydrogen and fission products released, and the effects of the high temperatures on the condition of the fuel after the high temperature drying. Fuel elements were visually examined and their condition recorded on video immediately after removal from the furnace.

\subsection{WATER RELEASED DURING COLD VACUUM DRYING}

The elements were kept damp by sprinkling them with deionized water during the handling and preparations for the drying test. The amount of surplus water could not be determined, however, there were no pools of water in the sample boat which held each fuel element.

Drying during the CVD portion of the test was accomplished using a combination of the condenser and the vacuum pumps. Water released during the CVD portion of the test is considered to be free water since oxy-hydrate 
decomposition is unlikely at $50{ }^{\circ} \mathrm{C}$. The amount of free water collected by the condenser ranged from $5 \mathrm{~m} \ell$ to $15 \mathrm{~m} \ell$. This did not represent the total amount of water removed since an unknown fraction of the moisture was released directly through the vacuum system. This fraction of moisture removed by the vacuum system could not be quantified but it is estimated to be no more than $50 \%$ of the total. Therefore, the quantity of free water removed from the sample elements during CVD is on the order of $10 \mathrm{~m} \ell$ to $30 \mathrm{~m} \ell$.

The residual free water inventory in an MCO after CVD was calculated based partly on the results of the whole element furnace tests (Pajunen 1998). An empirical correlation was developed for the furnace from the off-gas system tests relating the measured furnace pressure to gas flow rates. The water release rates obtained from the pressure correlation appear to be consistent with the measured water release rates for the furnace test during the CVD portion of the test cycle.

The elapse time for CVD was on the order of 5 hours for all the damaged elements except $2660 \mathrm{M}$ (Run 7 ). The time to remove the free water from the severely damaged $2660 \mathrm{M}$ element, with extensive axial cracking and breaches at both the top and bottom, was approximately twice the value for the other elements. Free water trapped in axial cracks may be harder to remove than free water from the open damaged ends of elements.

\subsection{WATER RETAINED AFTER COLD VACUUM DRYING}

The amount of bound water remaining after CVD is of prime importance in determining the Multi-Canister 0verpack (MCO) performance during the extended storage. Bound water is typically found as waters of hydration or as surface water. Hydrated water includes compounds with fuel, surface coating, and adhering sludge or corrosion products. Surface water is comprised of chemisorbed water and surface absorbed water. The quantities of water remaining after CVD were obtained by summing the quantities of water released during Steps 3 through 6 of the temperature cycle (Section 5.0). Results for the six damaged fuel elements are summarized in Table 3.

Approximately $90 \%$ of the water released from Element 0309M with the thick translucent coating is ascribed to the coating. This water was released at three different temperatures of approximately $130{ }^{\circ} \mathrm{C}, 187{ }^{\circ} \mathrm{C}$, and $222{ }^{\circ} \mathrm{C}$ (0liver 1998a). X-Ray diffraction measurements on coating material collected from a sibling element have shown the translucent coating to be $\mathrm{Al}(\mathrm{OH})_{3}$ which is approximately $35 \%$ water (Jenson 1997).

A $35 \%$ weight fraction of water converts to a total coating weight of $4.9 \mathrm{~g}$ for the $1.7 \mathrm{~g}$ of water released. The video examinations during sample retrieval suggest approximately $25 \%$ of the coating flaked off during the sample recovery. The fuel element cladding surface for the fractured $0309 \mathrm{M}$ element adjusted for the material lost during the element recovery corresponds to a coating density of approximately $5 \times 10^{-3} \mathrm{~g} / \mathrm{cm}^{2}$ of the element surface. Assuming the coating is $100 \%$ dense the coating thickness would be on the order of 25 microns. In-situ measurements of coating thickness on $\mathrm{K}$ West elements with aluminum hydroxide coatings ranged from 0 microns to 150 microns

(Pitner 1998b). 
Table 3. Summary of Water Remaining in the Damaged $K$ West Fuel Elements After Cold Vacuum Drying.

\begin{tabular}{|c|c|l|c|c||}
\hline $\begin{array}{c}\text { Furnace } \\
\text { Run }\end{array}$ & $\begin{array}{c}\text { Element } \\
\text { Number }\end{array}$ & \multicolumn{1}{|c|}{ Extent of Damage } & $\begin{array}{c}\text { Alumina } \\
\text { Hydroxide } \\
\text { Coating } \\
\text { Present }\end{array}$ & $\begin{array}{c}\text { Amount of } \\
\text { Water } \\
\text { Remaining } \\
\text { after CVD (g) }\end{array}$ \\
\hline 3 & $0309 M$ & Simple fracture at midpoint & Yes & $\begin{array}{c}1.9 \\
\text { (1.7 g } \\
\text { from coat ing) }\end{array}$ \\
\hline 4 & $5744 U$ & $\begin{array}{l}\text { Breached top, open cladding, } \\
\text { axial cracking }\end{array}$ & No & 1.1 \\
\hline 5 & $6603 M$ & Breached bottom, open cladding & No & 1.4 \\
\hline 6 & $1164 M$ & $\begin{array}{l}\text { Small top breach, extensive axial } \\
\text { cracks, some opening of cracks }\end{array}$ & No & 0.9 \\
\hline 7 & $2660 M$ & $\begin{array}{l}\text { Breached top, open cladding, open } \\
\text { axial cracks }\end{array}$ & No & 3.3 \\
\hline 8 & $6513 \mathrm{U}$ & $\begin{array}{l}\text { Breached top, open cladding, } \\
\text { bottom breached, open axial } \\
\text { cracks }\end{array}$ & No & 0.9 \\
\hline
\end{tabular}

The surface coating flaked off during the high temperature drying cycle and a total of $3.8 \mathrm{~g}$ were collected for analysis. Converting the material collected assumed to be $\mathrm{Al}_{2} \mathrm{O}_{3}$ after drying to $\mathrm{Al}(\mathrm{OH})_{3}$ results in a coating weight of $6.0 \mathrm{~g}$ (Makenas 1998). Scanning electron microscopy of an aluminum hydroxide coating from the sibling $K$ West fuel element showed coating thicknesses on the order of 40 microns to 60 microns. Therefore, the water released from the coatings correlates well with the total amount of coating collected at the end of the test and is consistent with coating thickness measurements on similar elements from $K$ West.

The amount of water remaining after CVD appears to be relatively insensitive to the extent of fuel damage once there has been fuel degradation and cladding opening (Table 3 ). Element 0309M had very 1 ittle water i.e., $0.2 \mathrm{~g}$ after CVD, exclusive of the moisture associated with the surface coating. Elements 5744U, 6603M, 1164M, and $6513 \mathrm{U}$ a 11 had about $1 \mathrm{~g}$ of water remaining after CVD. Element 2660M had the largest water inventory of $3.3 \mathrm{~g}$. Run 8 with another element classified as severely damaged was conducted to verify this larger water inventory. Element $6513 \mathrm{U}$ behaved more like the elements with lower moisture contents. An evaluation of the visible extent of fuel damage of this element established with the high resolution video camera in the hot cell during the pretest examinations supports behavior similar to the elements in Runs 4, 5, and 6 rather than Run 7 (01iver 1998c). 


\subsection{EFFECTS OF HIGH TEMPERATURE DRYING ON FUEL ELEMENT CONDITION}

Results of the post-test visual examination are summarized in Table 4. The aluminum hydroxide coating dried and changed to a white color and flaked off like an ash. This material was collected and analyzed (see Section 5.2 of this report). The light gray coatings characteristic of a large percentage of the $k$ West fuel element changed to a darker color is a result of the high temperature drying cycle. This material has been shown to be primarily iron based compounds which may have lost water or changed structure as a result of the drying (Makenas 1998).

The high temperature drying had no effect on the fracture surface of $0309 \mathrm{M}$ and appeared to have little effect on the open end breaches in elements $5744 \mathrm{U}, 6603 \mathrm{M}, 2660 \mathrm{M}$, and $6513 \mathrm{U}$ (Table 4). Drying did however, cause significant axial crack opening in three of the four elements with axial cracks.

Elements 1164M (Run 6) and 2660M (Run 7) showed extensive axial crack opening as a result of the high temperatures. Elements $6513 \mathrm{U}$ (Run 8 ) appears to have behaved differently. If crack opening is the result of oxidation of metallic fuel by moisture trapped under the cladding at the higher temperatures, this would suggest there was insufficient water trapped in the fuel cracks after CVD in 6513U to initiate the oxidation and subsequent volume expansion. The lack of water trapped in the axial crack in Element $6513 \mathrm{U}$ may also be responsible for the lower water inventory after CVD compared to Element $2660 \mathrm{M}$. Both elements were considered to be severely changed in appearance and Element $6513 \mathrm{U}$ was dried to verify the higher mo isture numbers for Element 2660M.

Table 4. Effects of High Temperature Drying on Fuel Element Condition.

\begin{tabular}{||c|c|l|l||}
\hline \multirow{2}{*}{$\begin{array}{c}\text { Run } \\
\text { Number }\end{array}$} & \multirow{2}{*}{$\begin{array}{c}\text { Element } \\
\text { Number }\end{array}$} & \multicolumn{2}{|c|}{ Effects of Drying on Fuel Element } \\
\cline { 3 - 5 } & $0309 \mathrm{M}$ & No effects on fracture & \multicolumn{1}{|c|}{$\begin{array}{c}\text { Coating dried and flaked } \\
\text { off }\end{array}$} \\
\hline 3 & $5744 \mathrm{U}$ & $\begin{array}{l}\text { Axial cracks opening with } \\
\text { possible dimensional } \\
\text { increases in region }\end{array}$ & $\begin{array}{l}\text { Coating may have darkened } \\
\text { in color }\end{array}$ \\
\hline 5 & $6603 \mathrm{M}$ & $\begin{array}{l}\text { No significant changes in } \\
\text { bottom breach }\end{array}$ & Coating darkened in color \\
\hline 6 & $1164 \mathrm{M}$ & $\begin{array}{l}\text { Extensive axial crack } \\
\text { opening }\end{array}$ & Coating darkened in color \\
\hline 7 & $2660 \mathrm{M}$ & $\begin{array}{l}\text { Extensive axial crack } \\
\text { opening }\end{array}$ & Coating darkened in color \\
\hline 8 & $6513 \mathrm{U}$ & $\begin{array}{l}\text { Some of the axial cracks } \\
\text { did not open further }\end{array}$ & Coating darkened in color \\
\hline
\end{tabular}


The lack of water trapped within the axial cracks may explain the difference in moisture inventory after CVD between Element 2660M (Run 7 ) and Element $6513 \mathrm{U}$ (Run 8). Moisture trapped in the axial cracks is available to react with the fuel forming uranium oxy-hydrates during the drying cycle, which will retain water at CVD temperatures but will release water at the higher temperatures used in the drying cycle.

\subsection{HYDROGEN RELEASE AND HYDRIDE DECOMPOSITION}

Hydrogen was released as a result of two processes ongoing in the drying cycle. Hydrogen is first released as the result of the interaction of water, released from the fuel, with the uranium surface resulting in oxidation of the uranium and the release of hydrogen. As the temperature was increased, the point was reached at which the hydrogen is released from the uranium hydrides, i.e., from $\mathrm{UH}_{3}$, present in the fuel matrix.

The Gas Chromatograph (GC) was calibrated to measure hydrogen in the sample gas. The GC yielded data for the release of hydrogen during the hot vacuum drying steps and from part of the cool down. It was not possible to sample the gas stream with the GC during the CVD portion of the drying cycle since CVD was conducted without a flow of carrier gas in the system.

Measured hydrogen release and the corresponding hydride decomposition are discussed in the following sections.

\subsubsection{Hydrogen Release}

Multiple peaks of hydrogen release were measured for all six damaged fuel elements. The location of these peaks are summarized in Table 5. Data can be grouped into the following four temperatures:

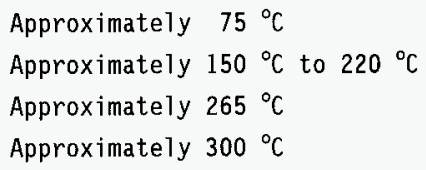

An examination of the moisture and hydrogen signals at $75{ }^{\circ} \mathrm{C}$ and $150{ }^{\circ} \mathrm{C}$ to $220{ }^{\circ} \mathrm{C}$ shows a strong correlation with the hydrogen release peaks suggesting that the hydrogen released at these two temperature ranges is the result of fuel oxidation by the water released through oxy-hydrate decomposition in the corrosion regions or in isolated regions under the cladding. Hydrogen released at approximately $265^{\circ} \mathrm{C}$ is attributed to $\mathrm{UH}_{3}$ decomposition since there was no correlation with the moisture released. This temperature is also close to the value expected for the decomposition of $\mathrm{UH}_{3}$ (Cotton 1988). Hydride decomposition will be discussed in detail in the next section. Hydrogen released at the higher temperatures of approximately $300^{\circ} \mathrm{C}$ is also considered to be due to fuel oxidation but in this case for surfaces that were not readily oxidized at the lower temperatures or fresh surfaces created as a result of crack opening during the temperature ramp to $400{ }^{\circ} \mathrm{C}$. 
Table 5. Summary of Observed Hydrogen

Release Peaks During Hot Vacuum Drying.

\begin{tabular}{||c|c|c|c|c|c|c||}
\hline $\begin{array}{c}\text { Furnace } \\
\text { Run }\end{array}$ & $\begin{array}{c}\text { Fue1 } \\
\text { Element }\end{array}$ & \multicolumn{6}{|c|}{ Temperature for Peaks in the Hydrogen Released ${ }^{\circ} \mathrm{C}$} \\
\hline 3 & $0309 \mathrm{M}$ & $\sim 75$ & & 220 & 265 & $\sim 300$ \\
\hline 4 & $5744 \mathrm{U}$ & $\sim 75$ & & 170 & 265 & $\sim 300$ \\
\hline 5 & $6603 \mathrm{M}$ & $\sim 75$ & 127 & 167 & 253 & $\sim 300$ \\
\hline 6 & $1164 \mathrm{M}$ & $\sim 75$ & 155 & & 260 & \\
\hline 7 & $2660 \mathrm{M}$ & $\sim 75$ & 152 & 194 & 245 & \\
\hline 8 & $6513 \mathrm{U}$ & $\sim 75$ & 148 & 208 & 257 & \\
\hline
\end{tabular}

Hydrogen release curves for each run showing the peaks and the integrated amounts of hydrogen released at each peak can be found in the baseline references (Section 6.1) and are not included in this summary report.

\subsubsection{Hydride Decomposition}

The individual hydrogen peaks were deconvoluted and the quantity of hydrogen obtained for the temperature peak associated with approximately $265^{\circ} \mathrm{C}$. Results of the analys is are summarized in Table 6 . In general the hydrogen release at $265{ }^{\circ} \mathrm{C}$ represents the largest fraction of total hydrogen released. The quantity of hydrogen released was converted to the amount of $\mathrm{UH}_{3}$ in the fuel that decomposed to release that corresponding amount of hydrogen.

The amount of hydride decomposed appears to correlate with the extent of fuel damage. The lowest hydride content decomposed corresponds to the element, i.e., 0309M, with the least amount of damage. Element 1164M in Run 6 had the largest hydrogen release which corresponds to an element characterized by extensive axial cracking and no open breaches. This large area of fuel cracks with minimal corrosion may have contained the largest concentration of hydrides.

Metallographic examination of the breached area of a $K$ West element showed the hydrides to reside along fuel cracks which have communication with the outer surface (Marschman 1997). The hydrides were more prevalent in the micro-cracked region of the reacted fuel surface. Hydrides did however, appear throughout the surface examined. Additionally, uranium hydride was distributed in the fuel matrix adjacent to the cracks with the cracks acting as conduits for carrying the hydrogen from the corroded surface deeper into the fuel matrix. 
Table 6. Summary of Total Hydrogen Released During Drying and from Hydride Decomposition.

\begin{tabular}{|c|c|c|c|c|}
\hline \multirow{2}{*}{$\begin{array}{l}\text { Furnace } \\
\text { Run }\end{array}$} & \multirow{2}{*}{$\begin{array}{c}\text { Fue1 } \\
\text { Element }\end{array}$} & \multicolumn{2}{|c|}{ Hydrogen Released (mg) } & \multirow{2}{*}{$\begin{array}{c}\text { Corresponding } \\
\mathrm{UH}_{3} \text { Content* }(\mathrm{g}\end{array}$} \\
\hline & & At $265^{\circ} \mathrm{C}$ & Total & \\
\hline 3 & $0309 \mathrm{M}$ & 5 & 19 & 0.5 \\
\hline 4 & $5744 \mathrm{U}$ & 73 & 200 & 6 \\
\hline 5 & $6603 \mathrm{M}$ & 6.6 & 77 & 0.6 \\
\hline 6 & $1164 M$ & 460 & 480 & 40 \\
\hline 7 & $2660 M$ & 100 & 190 & 8 \\
\hline 8 & $6513 U$ & 107 & 190 & 9 \\
\hline
\end{tabular}

*Converting the quantity of hydrogen released at $265{ }^{\circ} \mathrm{C}$ to corresponding weight of $\mathrm{UH}_{3}$ decomposed.

Element $6603 \mathrm{M}$ with a bottom breach exhibited low hydride contents. This breach may have been covered with sludge at the bottom of its storage canister while in the $\mathrm{K}$ West Basin. This may possibly account for the lower hydride content compared to elements with top breaches and unimpeded communication with the water or the upper gas plenum in the sealed canisters.

Elements $2660 \mathrm{M}$ and $6513 \mathrm{U}$ with extensive damage and significant fuel loss have relatively small quantities of hydride. This may be the result of the significant fuel loss in that the remaining fuel material contains a minimal amount of hydrides as a result of the corrosive process.

\subsection{FISSION PRODUCTS RELEASED}

The Mass Spectrometer capable of scanning to 300 atomic mass units was used to monitor hydrogen, nitrogen (for air in-leakage) krypton, xenon, and other elements during the tests. Test segments are monitored with the mass spectrometer for $\mathrm{H}_{2}, \mathrm{H}_{2} \mathrm{O}, \mathrm{N}_{2}, \mathrm{O}_{2}, \mathrm{CO}_{2}, \mathrm{Ar}, \mathrm{Kr}$, and $\mathrm{Xe}$. There were no significant krypton or xenon releases measured from Runs 3 or 4 . A very small rise in xenon and krypton signals was observed during the pressure rise portion of the temperature cycle which is likely due to the release of fission gases from oxidation of the fuel at $50{ }^{\circ} \mathrm{C}$ The static conditions during the pressure rise test provided an opportunity for the accumulation of these gases to detectable levels (0liver 1998a; Klinger 1998a).

Measurable quantities of xenon and krypton were released from Elements 6603M and 1164M in furnace Runs 5 and 6 (Marschman 1998b; 01 iver 1998b). Xenon released from Element 6603M in Run 5 during the hot vacuum drying is shown in Figure 5 . Xenon is released from the fuel matrix during oxidation and to a smaller extent during the thermal decomposition of the uranium hydride. The general shape of the xenon release curve matches similar trends in both the water and hydrogen releases. 
Figure 5. Normalized Xenon Release During Hot Vacuum Drying of Spent Nuclear Fuel Element 6603M (Run 5).

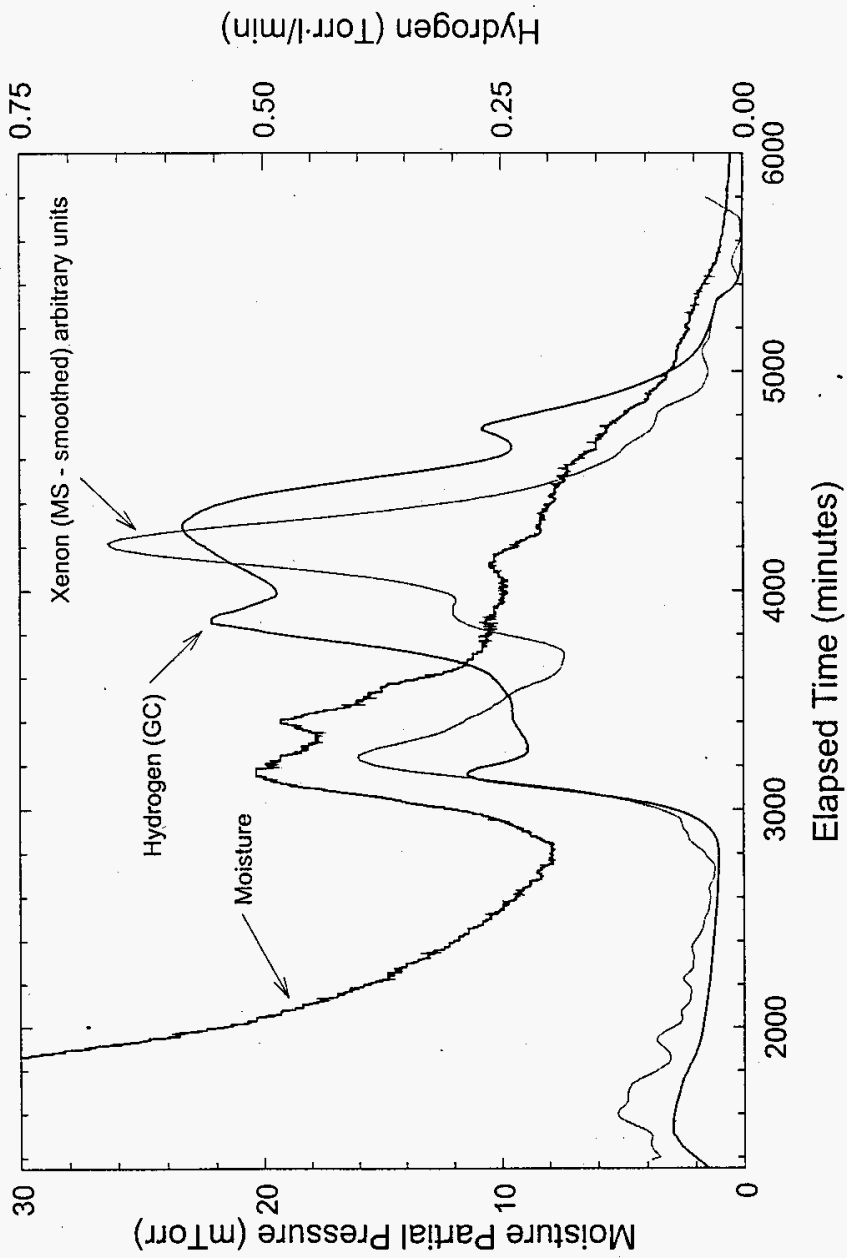




\section{HNF-3377, Rev. 0}

The magnitudes and isotopic composition of the various xenon isotopes for Run 5 were compared to calculated values based on the ORIGEN2 computer code (Marschman 1998b). Relative xenon isotopic release rates during the pressure rise tests were found to agree very closely with the calculated percentages.

Similar fission gas xenon behavior was noted in Run 6 . Mass spectrometer data for Runs 7 and 8 are unavailable due to technical problems encountered with the equipment during these two furnace runs. 
HNF-3377, Rev. 0

This page intentionally left blank. 


\subsection{REFERENCES}

\subsection{BASELINE REFERENCES FOR FURNACE RUNS 1 THROUGH 8}

Flament, T. A., J. Abrefah, G. S. Klinger, B. M. 01 iver, S. C. Marschman, P. J. MacFarlan, and G. A. Ritter, 1998, Drying Results of K Basin Fuel Element 3128 W (Run 2)," PNNL-11818, Pacific Northwest National Laboratory, Richland, Washington.

Klinger, G. S., B. M. Oliver, J. Abrefah, P. J. MacFarlan, S. C. Marschman, and G. A. Ritter, 1998a, Drying Results of $K$ Basin Fuel Element $5744 U$ (Run 4), PNNL-11821, Pacific Northwest National Laboratory, Richland, Washington.

Klinger, G. S., B. M. 01 iver, J. Abrefah, P. J. MacFarlan, S. C. Marschman, and G. A. Ritter, 1998b, Drying Results of K Basin Fuel Element 2660M (Run 7), PNNL-11897, Pacific Northwest National Laboratory, Richland, Washington.

Marschman, S. C., J. Abrefah, G. S. Klinger, B. M. Oliver, P. J. MacFarlan, and G. A. Ritter, 1998a, Drying Results of $K$ Basin Fuel Element 1990 (Run 1), PNNL-11817, Pacific Northwest National Laboratory, Richland, Washington.

Marschman, S. C., J. Abrefah, L. R. Greenwood, G. S. Klinger, P. J. MacFarlan, B. M. 01 iver, and G. A. Ritter, 1998b, Drying Results of K Basin Fue 7 Element $6603 \mathrm{M}$ (Run 5), PNNL-11841, Pacific Northwest National Laboratory, Richland, Washington.

01 iver, B. M., G. S. Klinger, J. Abrefah, S. C. Marschman, P. J. MacFarlan, and G. A. Ritter, 1998a, Drying Results of $K$ Basin Fuel Element 0309M (Run 3), PNNL-11820, Pacific Northwest National Laboratory, Richland, Washington.

01iver, B. M., G. S. Klinger, J. Abrefah, S. C. Marschman, P. J. MacFarlan, and G. A. Ritter, 1998b, Drying Results of $K$ Basin Fuel Element $1164 M$ (Run 6), PNNL-11896, Pacific Northwest National Laboratory, Richland, Washington.

0liver, B. M., G. S. Klinger, J. Abrefah, S. C. Marschman, P. J. MacFarlan, and G. A. Ritter, 1998c, Drying Results of $K$ Basin Fuel Element $6513 U$ (Run 8), PNNL-11969, Pacific Northwest National Laboratory, Richland, Washington.

\subsection{SUPPORTING REFERENCES}

Abrefah, J., S. C. Marschman, and E. D. Jensen, 1998a, Examination of the Surface Coatings Removed from K East Basin Fuel Elements, PNNL-11806, Pacific Northwest National Laboratory, Richland, Washington. 


\subsection{SUPPORTING REFERENCES (Continued)}

Abrefah, J., H. C. Buchanan, W. M. Gerry, W. J. Gray, and S. C. Marschman, 1998b, Dry Air Oxidation Kinetics of K Basin Spent Nuclear Fuel, PNNL-11786, Pacific Northwest National Laboratory, Richland, Washington.

Cotton, F. A., 1988, "Advanced Inorganic Chemistry," 5th Edition, John Wiley \& Sons, New York, New York.

Jenson, E. D., 1997, "XRD Examination of Sample SFEC 12-96-2 0161M SDI CS4," Internal Memo to K. L. Silvers, dated October 16, 1997, Pacific Northwest National Laboratory, Richland, Washington.

Klinger, G. S., B. M. 0liver, J. Abrefah, S. C. Marschman, P. J. MacFarlan, and G. A. Ritter, 1998c, Spent Fuel Drying System Test Results (First Dry Run), PNNL-11814, Pacific Northwest National Laboratory, Richland, Washington.

Klinger, G. S., B. M. 01 iver, J. Abrefah, S. C. Marschman, P. J. MacFarlan, and G. A. Ritter, 1998d, Spent Fuel Drying System Test Results (Second Dry Run), PNNL-11838, Pacific Northwest National Laboratory, Richland, Washington.

Lawrence, L. A., 1998, Strategy for Phase II Whole Element Furnace Testing $K$ West Fuel, HNF-2315, Rev. 0, Duke Engineering \& Services Hanford, Inc., Richland, Washington.

Lawrence, L. A., B. J. Makenas, and D. W. Bergmann, 1997a, Data Quality Objectives for the Second $k$ West Fuel Examinations, HNF-SD-SNF-DQ0-011, Rev. 0, Duke Engineering \& Services Hanford, Inc., Richland, Washington.

Lawrence, L. A., 1997b, Strategy for Examination of the Fifteen $K$ West Basin Fuel Elements, HNF-SD-SNF-SP-018, Rev. 0, Duke Engineering \& Services Hanford, Inc., Richland, Washington.

Lawrence, L. A., 1996a, Strategy for Examination of the Initial Nine K East Basin Fuel Elements, WHC-SD-SNF-SP-014, Rev. 0, Westinghouse Hanford Company, Richland, Washington.

Lawrence, L. A., 1996b, Data Quality Objectives for the $K$ East Fue Examinations, WHC-SD-SNF-DQ0-009, Rev. 0, Westinghouse Hanford Company, Richland, Washington.

Makenas, B. J., 1998, "Recent Aluminum Hydroxide Data," Internal Memo to R. P. Omberg, dated February 24, 1998, Duke Engineering \& Services Hanford, Inc., Richland, Washington.

Marschman, S. C., T. D. Pyecha, and J. Abrefah, Metallographic Examination of Damaged N Reactor Spent Nuclear Fuel Element SFEC5, 4378, PNNL-11438, Pacific Northwest National Laboratory, Richland, Washington. 


\subsection{SUPPORTING REFERENCES (Continued)}

Pajunen, A. L., 1998, Cold Vacuum Drying Residual Free Water Test Description, HNF-1851, Rev. 1, COGEMA Engineering Corporation, Richland, Washington.

Pitner, A. L., 1998a, Summary Assessment of Fuel Damage Distributions in the $K$ Basins, HNF-2586, Rev. 0, Duke Engineering \& Services Hanford, Inc., Richland, Washington.

Pitner, A. L., and S. L. Hecht, 1998b, Aluminum Hydroxide Coating Thickness Measurements and Brushing Tests on $K$ West Basin Fuel Elements, HNF-3283, Rev. 0, Duke Engineering \& Services Hanford, Inc., Richland, Washington.

Pitner, A. L., 1997a, Visual Examinations of $K$ West Fuel Elements, HNF-SD-SNF-TI-046, Rev. 0, Duke Engineering \& Services Hanford, Inc., Richland, Washington.

Pitner, A. L., 1997b, In-Cell Visual Examinations of $K$ East Fuel Elements, HNF-SD-SNF-TI-050, Rev. 0, Duke Engineering \& Services Hanford, Inc., Richl and, Washington.

Pitner, A. L., 1997c, K Basin Fuel Subsurface Examinations and Surface Coating Sampling, HNF-SD-SNF-TI-060, Rev. 0, Duke Engineering \& Services Hanford, Inc., Richland, Washington.

Ritter, G. A., 1998, System Design Description for Whole Element Furnace Testing System, PNNL-11807, Pacific Northwest National Laboratory, Richl and, Washington. 
HNF-3377, Rev. 0

This page is intentionally left blank. 
HNF-3377, Rev. 0

A P P E N D I X A

DRYING RESULTS FOR WHOLE ELEMENT FURNACE RUNS 3 THROUGH 8 
HNF-3377, Rev. 0

This page intentionally left blank. 
Figure A1. Summary Plot of Drying of Spent Nuclear Fuel Element 0309M (Run 3).

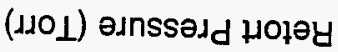

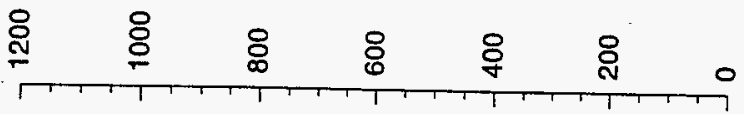

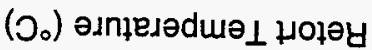

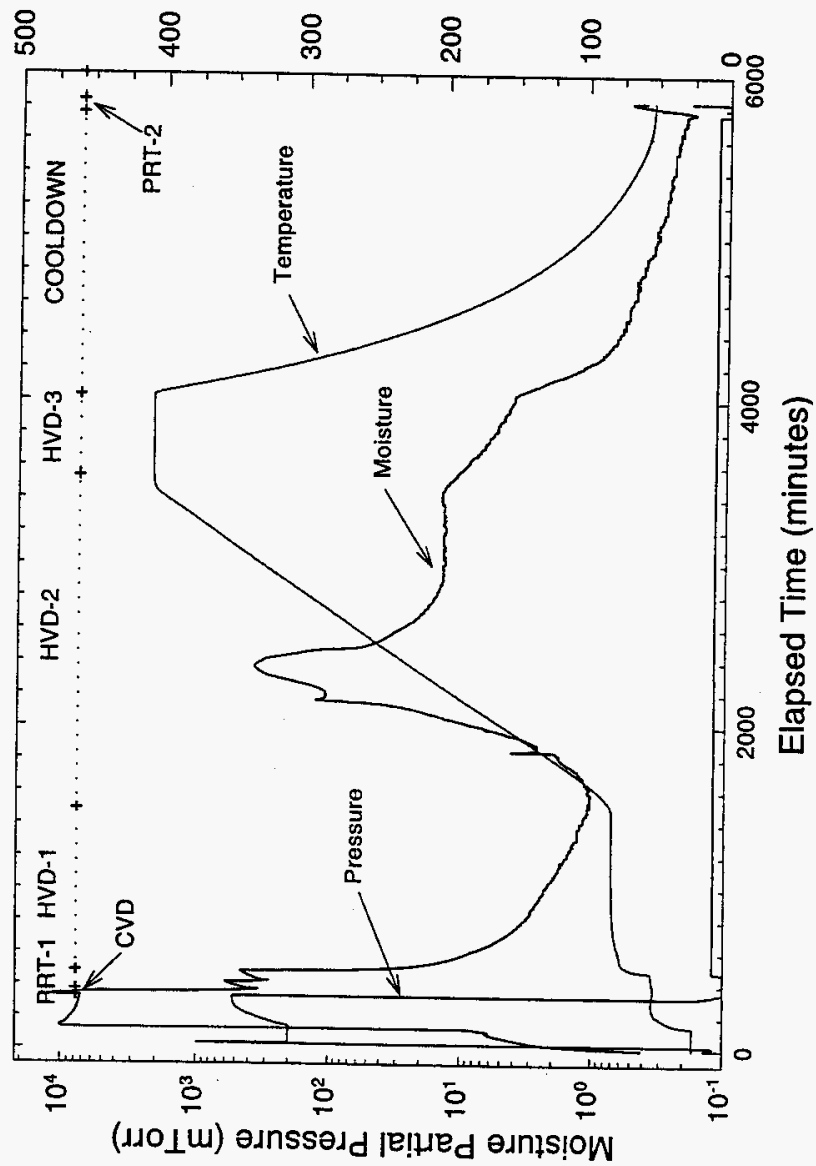


HNF-3377, Rev. 0

Figure A2. Summary Plot of Drying of Spent Nuclear Fuel Element 5744 U (Run 4).

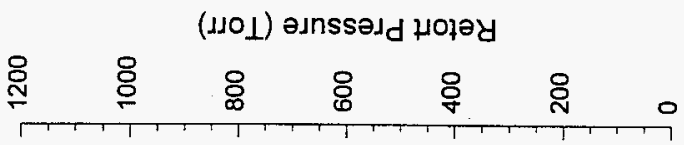

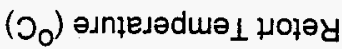

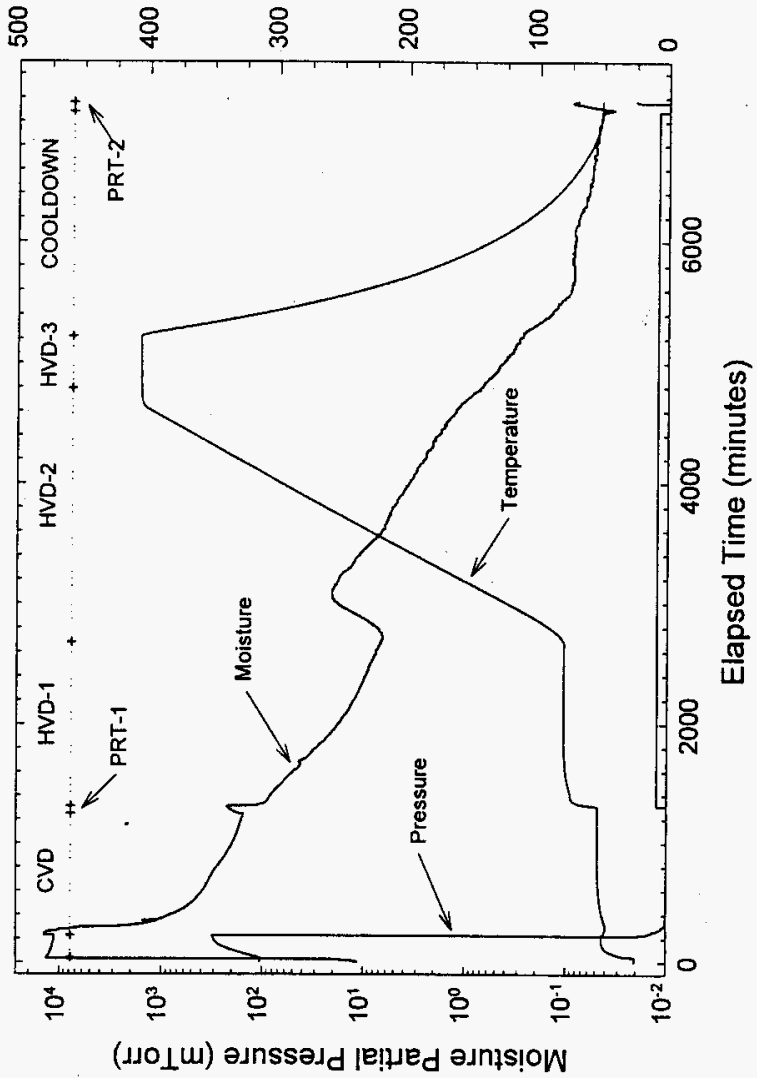


HNF-3377, Rev. 0

Figure A3. Summary Plot of Drying of Spent Nuclear Fuel Element 6603M (Run 5).

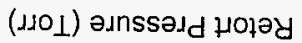

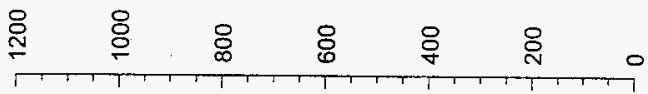

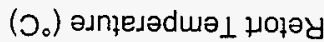
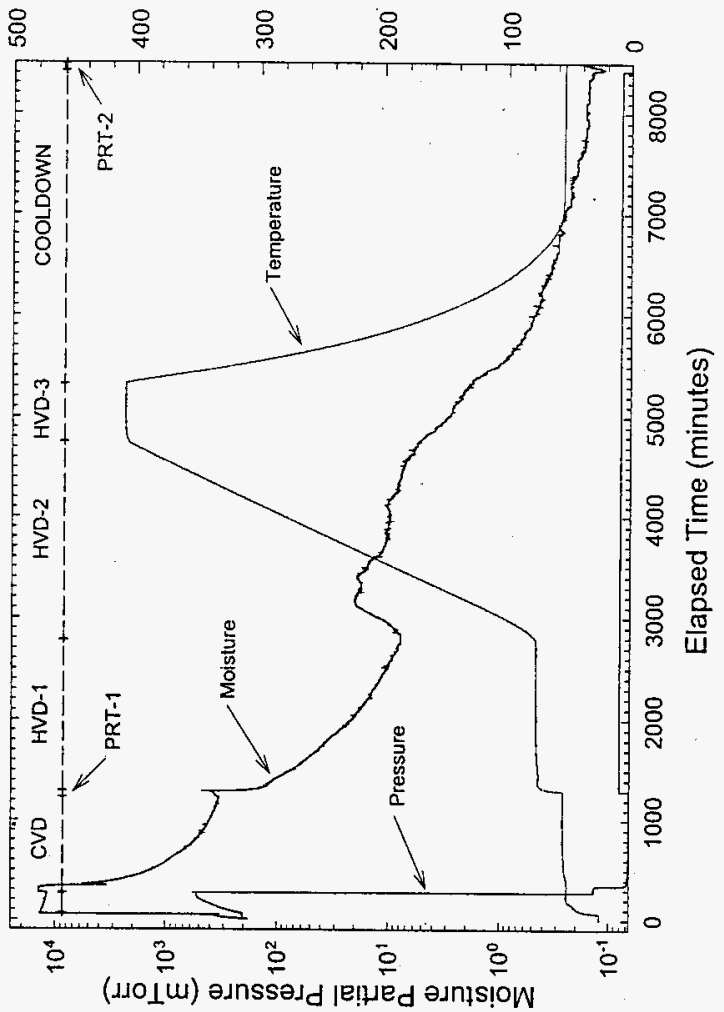
HNF-3377, Rev. 0

Figure A4. Summary Plot of Drying of Spent Nuclear Fuel Element 1164M (Run 6).

(ג.1) zנnssedd Holəy

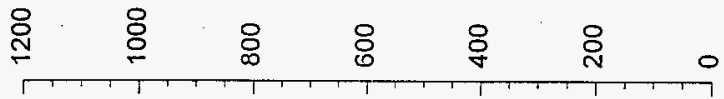

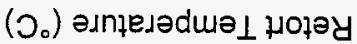
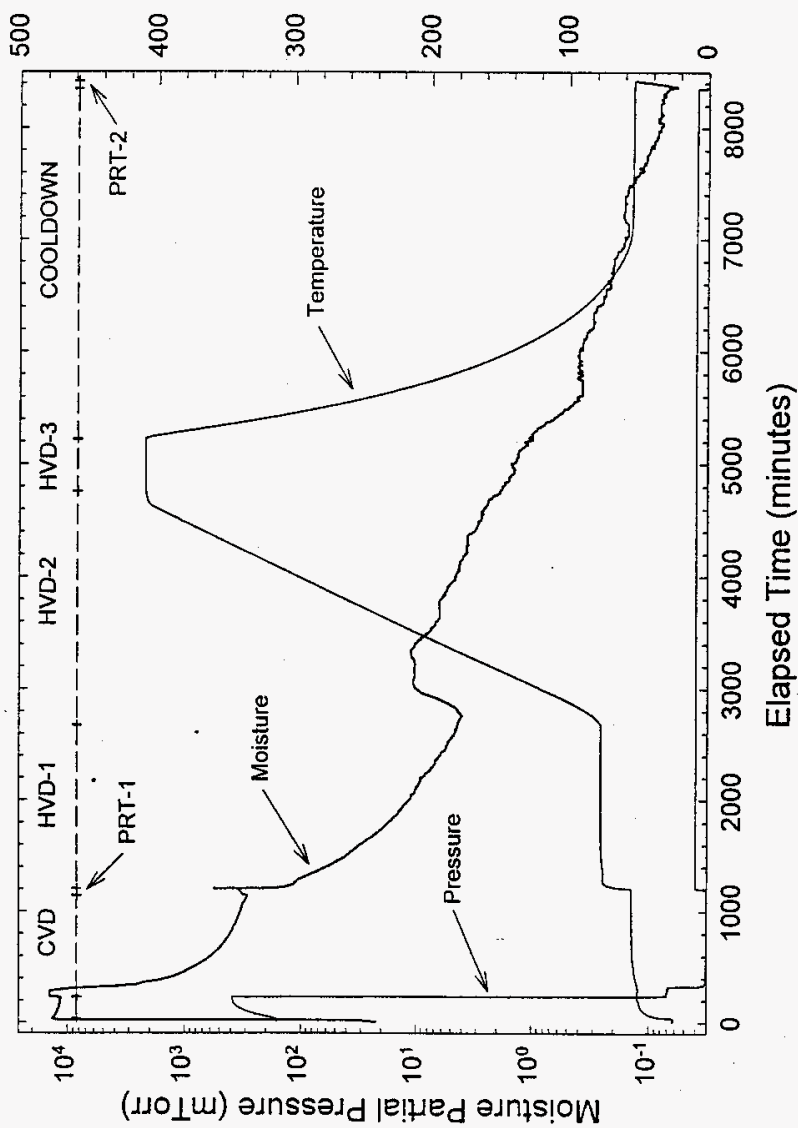
HNF-3377, Rev. 0

Figure A5. Summary Plot of Drying of Spent Nuclear Fuel Element 2660M (Run 7).
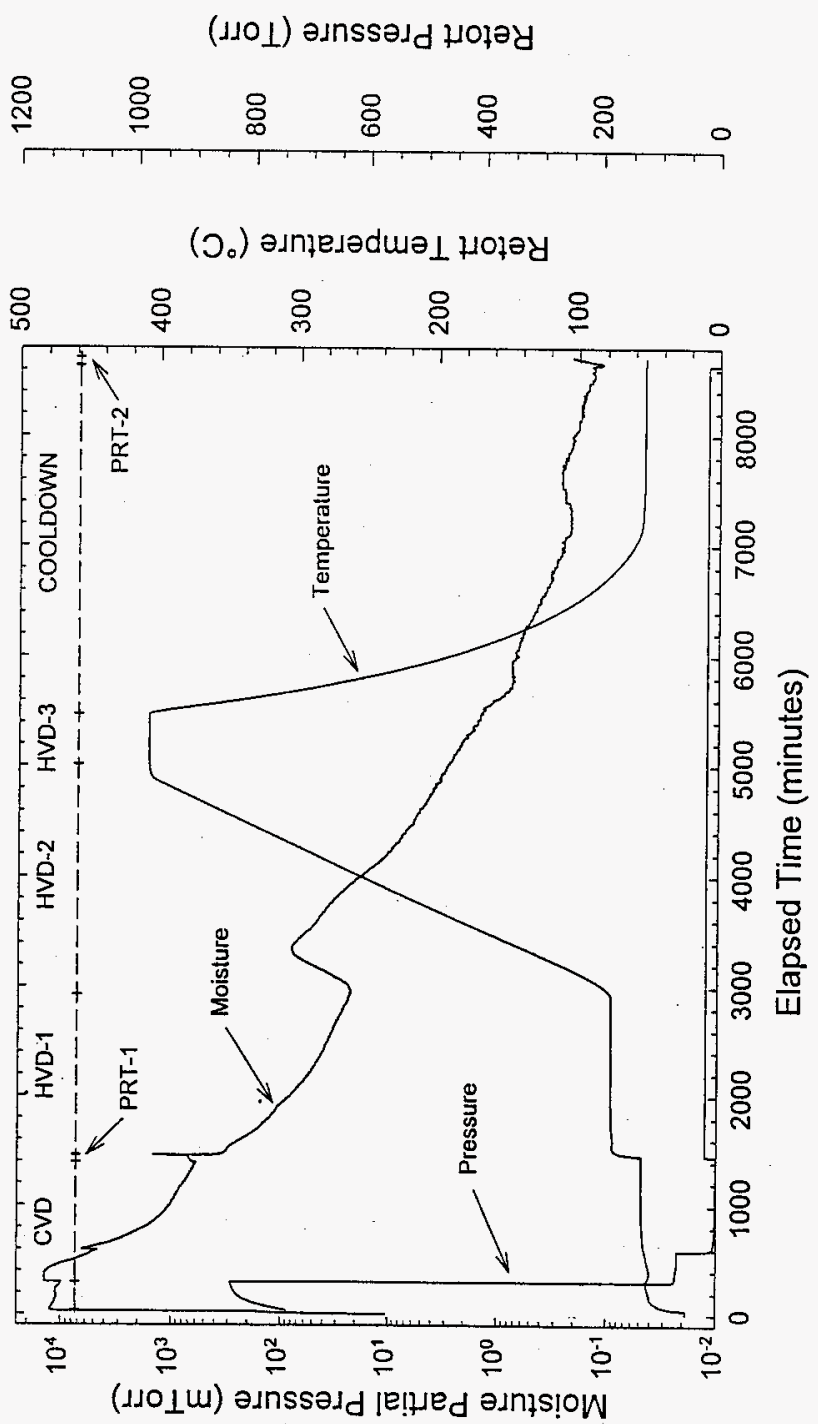
Figure A6. Summary Plot of Drying of Spent Nuclear Fuel Element 6513U (Run 8).

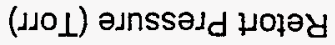

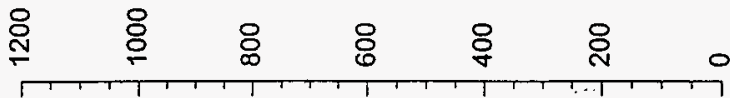

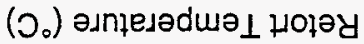

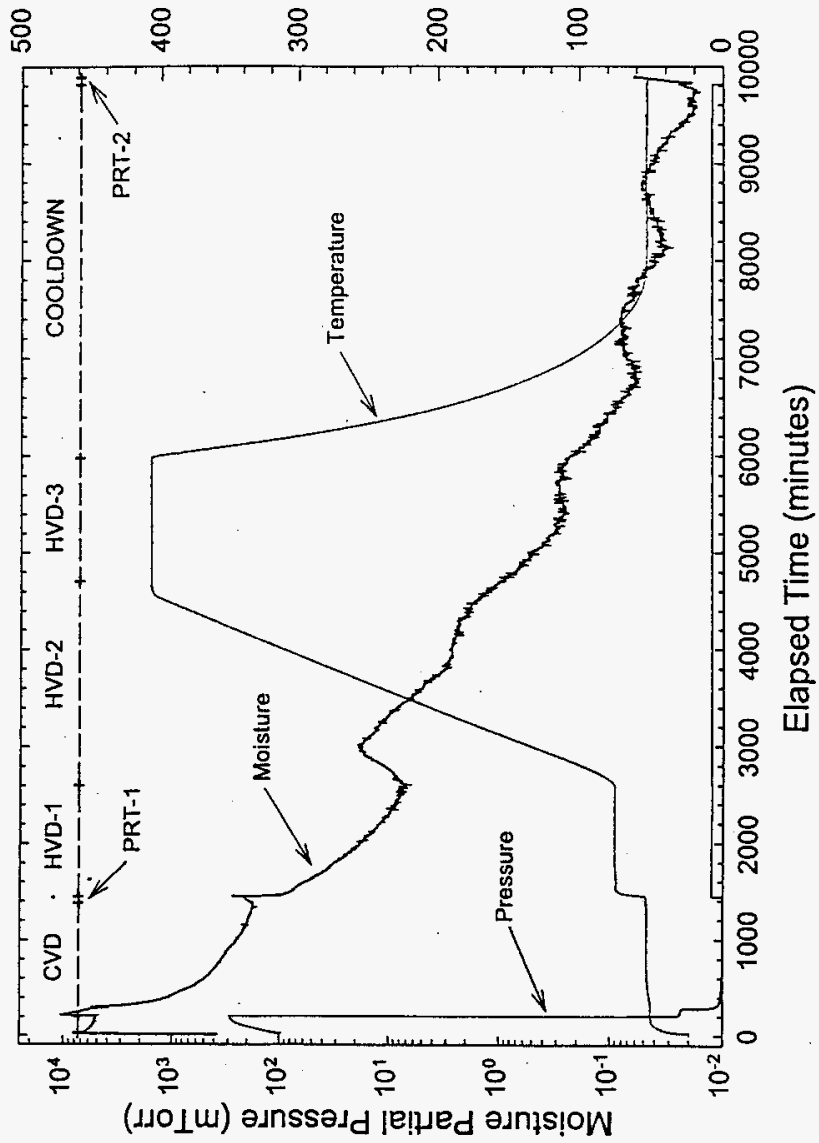




\section{DISTRIBUTION SHEET}

\begin{tabular}{|c|c|c|c|c|c|}
\hline \multirow{2}{*}{$\begin{array}{l}\text { To } \\
\text { Distribution }\end{array}$} & \multirow{2}{*}{\multicolumn{3}{|c|}{$\begin{array}{l}\text { From } \\
\text { SNF Characterization Project/ } \\
\text { 2T960 }\end{array}$}} & \multicolumn{2}{|l|}{ Page 1 of 2} \\
\hline & & & & \multicolumn{2}{|c|}{ Date October 1998} \\
\hline \multicolumn{4}{|l|}{ Project Title/Work Order } & \multicolumn{2}{|c|}{ EDT No. 620816} \\
\hline \multicolumn{4}{|c|}{$\begin{array}{l}\text { Drying Damaged } K \text { west Fuel Elements (Summary of Whole Element } \\
\text { Furnace Runs } 1 \text { through } 8 \text { )/HNF-3377, Rev. } 0\end{array}$} & \multicolumn{2}{|l|}{ ECN No. } \\
\hline Name & MSIN & $\begin{array}{l}\text { Text } \\
\text { With All } \\
\text { Attach. }\end{array}$ & Text Only & $\begin{array}{l}\text { Attach./ } \\
\text { Appendix } \\
\text { Only }\end{array}$ & $\begin{array}{l}\text { EDT/ECN } \\
\text { Only }\end{array}$ \\
\hline
\end{tabular}

Fluor Daniel Hanford. Inc.
E. W. Gerber
R3-11
$x$

COGEMA Engineering Corporation
A. L. Pajunen
R3-86
$x$

Duke Engineering \& Services Hanford, Inc.
R. B. Baker
D. W. Bergmann
J. R. Frederickson
L. A. Lawrence (5)
B. J. Makenas
R. P. Omberg
A. L. Pjtner
A. M. Segrest
J. A. Swenson
D. J. Trimble
SNF Project File

Lockheed Martin Services, Inc.

\section{Central Files}

DPC

Numatec Hanford Corporation
T. A. Flament
C. R. Miska
J. P. Sloughter

$\mathrm{HO}-40$

$\mathrm{HO}-40$

R3-86

HO- 40

$\mathrm{HO}-40$

HO- 40

$\mathrm{HO}-40$

R3-11

R3-11

HO-40

R3-11

$\mathrm{BI}-07$

A3-88

A3-89

$X$
$X$

$\begin{array}{ll}H 7-20 & X \\ \text { R3-86 } & X \\ H 0-34 & X\end{array}$

Idaho National Engineering \& Environmental Laboratory Post Office Box 1625

Idaho Falls, Idaho 83415

C. L. Bendixsen

R. L. Brattion 


\begin{tabular}{|c|c|c|c|c|c|}
\hline \multirow{2}{*}{$\begin{array}{l}\text { To } \\
\text { Distribution }\end{array}$} & \multirow{2}{*}{\multicolumn{3}{|c|}{$\begin{array}{l}\text { From } \\
\text { SNF Characterization Project/ } \\
\text { 2T960 }\end{array}$}} & \multicolumn{2}{|l|}{ Page 2 of 2} \\
\hline & & & & \multicolumn{2}{|c|}{ Date October 1998} \\
\hline \multicolumn{4}{|l|}{ Project Title/Work Order } & \multicolumn{2}{|c|}{ EDT No. 620816} \\
\hline \multicolumn{4}{|c|}{$\begin{array}{l}\text { Drying Damaged } K \text { West Fuel Elements (Summary of Whole Element } \\
\text { Furnace Runs } 1 \text { through } 8 \text { )/HNF-3377, Rev. } 0\end{array}$} & \multicolumn{2}{|l|}{ ECN No. } \\
\hline Name & MSIN & $\begin{array}{l}\text { Text } \\
\text { With All } \\
\text { Attach. }\end{array}$ & Text Only & $\begin{array}{l}\text { Attach./ } \\
\text { Appendix } \\
\text { Only }\end{array}$ & $\begin{array}{l}\text { EDT/ECN } \\
\text { Only }\end{array}$ \\
\hline
\end{tabular}

Pacific Northwest National Laboratory

J. Abrefah

G. S. Klinger

S. C. Marschman

B. M. 01 iver

$\begin{array}{ll}\text { P7-27 } & X \\ \text { P7-22 } & X \\ \text { P7-47 } & X \\ \text { P7-22 } & X\end{array}$

Technical Advisory Group

J. C. Devine R3-11 X

U.S. Department of Energy, Richland Operations Office

R. M. Hiegel

P. G. Loscoe

J. Shuen

Washington State Department of Ecology Post Office Box 47600

0lympia, Washington 98504-7600

D. Silver

Washington State Department of Health Airdustrial Park

Building 5, Mail Stop LE-13

0lympia, Washington 98504-0095

A. W. Conk 7 in

Yucca Mountain Project M\&O Contractor SUM $1 / 423$

1261 Town Center Drive

Las Vegas, Nevada 89134

T. A. Thornton

DOE Reading Room

H2-53

S7-41

S7-41

S7-41

$x$

$x$

$x$ 